\title{
Global Public Interests and Dynamic Trends in Osteoporosis From 2004 to 2019: Infodemiology Study
}

Peng Wang, PhD; Qing Xu, MPH; Rong-Rong Cao, PhD; Fei-Yan Deng, PhD; Shu-Feng Lei, PhD

Center for Genetic Epidemiology and Genomics, School of Public Health, Soochow University Medical College, Soochow University, Suzhou, China

Corresponding Author:

Shu-Feng Lei, PhD

Center for Genetic Epidemiology and Genomics, School of Public Health

Soochow University Medical College

Soochow University

199 Renai Road

Suzhou, 215123

China

Phone: 8651265883227

Fax: 8651265883227

Email: leisf@suda.edu.cn

\section{Abstract}

Background: With the prolonging of human life expectancy and subsequent population aging, osteoporosis (OP) has become an important public health issue.

Objective: This study aimed to understand the global public search interests and dynamic trends in "osteoporosis" using the data derived from Google Trends.

Methods: An online search was performed using the term "osteoporosis" in Google Trends from January 1, 2004, to December 31, 2019, under the category "Health." Cosinor analysis was used to test the seasonality of relative search volume (RSV) for "osteoporosis." An analysis was conducted to investigate the public search topic rising in RSV for "osteoporosis."

Results: There was a descending trend of global RSV for "osteoporosis" from January 2004 to December 2014, and a slowly increasing trend from January 2015 to December 2019. Cosinor analysis showed significant seasonal variations in global RSV for "osteoporosis" $(P=.01)$, with a peak in March and a trough in September. In addition, similar decreasing trends of RSV for "osteoporosis" were found in Australia, New Zealand, Ireland, and Canada from January 2004 to December 2019. Cosinor test revealed significant seasonal variations in RSV for "osteoporosis" in Australia, New Zealand, Canada, Ireland, UK, and USA (all $P<.001$ ). Furthermore, public search rising topics related to "osteoporosis" included denosumab, fracture risk assessment tool, bone density, osteopenia, osteoarthritis, and risk factor.

Conclusions: Our study provided evidence about the public search interest and dynamic trends in OP using web-based data, which would be helpful for public health and policy making.

(J Med Internet Res 2021;23(7):e25422) doi: 10.2196/25422

\section{KEYWORDS}

global public interest; Google trends; osteoporosis; seasonality; trends; infodemiology; information seeking; web-based information

\section{Introduction}

\section{Overview}

Osteoporosis (OP) is a generalized skeletal disorder characterized by reduction in bone mineral content, low bone mineral density, and deterioration of bone structure, all of which will eventually lead to bone fragility and an increased susceptibility to fracture [1-3]. OP is commonly described as a "silent disease" because it lacks obvious signs, and has now become an important public health issue, with estimates indicating that nearly 200 million individuals are impacted worldwide [4]. Multiple risk factors are thought to contribute to the increased likelihood of OP, including sex, age, race, hormone levels, dietary factors, and lifestyle choices [5-7].

Globally, internet has become an important platform for people to seek and share health-related information. The vast amount of new data derived from social media and search engines has shown potential values in investigating, nowcasting, and 
forecasting human behaviors and diseases [8,9]. Research on internet data are usually referred to as "infodemiology studies" $[10,11]$.

Infodemiology is defined as "the science of distribution and determinants of information in an electronic medium, specifically the Internet, or in a population, with the ultimate aim to inform public health and public policy" [10,11]. Infodemiology data can be collected from social media sources (Facebook, Twitter, and Instagram) and search engines (Google, Bing, and Baidu) in near real-time [12,13]. Such data allow to predict outbreaks of diseases, aid in monitoring disease syndromic surveillance as well as in detecting and quantifying disparities in health information availability [14].

\section{Google Trends}

Google Trends, as an accessible online tool, provides both real-time and archived information on Google search queries from 2004. So far, many studies have demonstrated that Google Trends could be regarded as a reliable tool for examining human behaviors, measuring the change in interest in controversial issues, analyzing public's reaction to various outbreaks or incidents, and investigating seasonal trends related to various diseases and health issues [15-20]. This new approach is also gaining importance in disease surveillance studies and could serve as an effective complement to traditional, time-consuming survey methods [21-25].

Google Trends has increasingly become a meaningful health source for both laypeople and health professionals. The web-based information on Google Trends has been recognized as a surrogate tool for estimating epidemiology and gathering data on patterns of disease and human behaviors [15,20,23]. In fact, data from internet sources could serve as a real-time surveillance tool and a supplement for health care systems, so as to allocate appropriate resources for specific moments with higher disease burden.

Google Trends, however, has not yet been used to investigate the public search interest and trends in OP. Therefore, we conducted this study to better understand the utility of Google Trends data for exploring global public search interest and dynamic trends in OP over time.

\section{Methods}

\section{Keyword Selection}

Data on internet search for "osteoporosis" were obtained from Google Trends, which provided the relative search volume (RSV) for the aforesaid search term. To make reasonable comparisons between different search terms, Google Trends adjusts the search results to the time and location of a search term by dividing each data point by the total searches of the geography and period, and then by scaling these resulting numbers based on a given search term's proportion. The higher scores represent higher RSV. The data points can be downloaded from Google Trends in ".csv" format. To avoid selection bias, Google Trends excludes all of the repeated searches from the same person during a short span of time [15].

\section{Region and Period Selection}

On April 20, 2020, the keyword "osteoporosis" was searched by individually selecting the countries "Worldwide," "Australia," "New Zealand," "Canada," "Ireland," "UK," and "USA" and choosing the category as "Health." The corresponding time-series data from January 2004 to December 2019 were then downloaded. The time-series data in our study were not a product of comparison between countries, but rather a longitudinal data on the RSV for "osteoporosis" in a single country. The period selection was representative and appropriate for our study, and contained retrospective data over the past 16 years.

\section{Statistical Analysis}

Cosinor analysis was utilized to investigate the seasonal patterns of RSV for "osteoporosis," where the RSV was regressed onto a sine and a cosine term of transformations of the time variable and represented as a sine curve that could be applied to test the seasonality $[26,27]$. A time-series plot was used to demonstrate the consistency in seasonal patterns. Statistical analysis on seasonality was conducted using the "season" package in R version 3.4.4 (R Foundation for Statistical Computing), while an analysis on OP-related topics was performed using Google Trends data [28]. Statistical significance was set as 2-tailed $P<.05$.

\section{Availability of Data and Material}

The data and material that support the findings of this study are available from public data sets that could be found in Google Trends.

\section{Results}

\section{Global Search Popularity for "Osteoporosis"}

As displayed in Figure 1, the color intensity represents the RSV of Google searches performed during the studied period. The highest RSV for "osteoporosis" was found in Bolivia (100), Peru (95), Ireland (95), Australia (91), Bulgaria (87), Denmark (87), Singapore (73), Mongolia (73), South Africa (73), UK (69), New Zealand (69), USA (65), Panama (65), Puerto Rico (60), and Canada (60). 
Figure 1. Graphic map of search popularity for "osteoporosis" by location (worldwide). RSV: relative search volume.

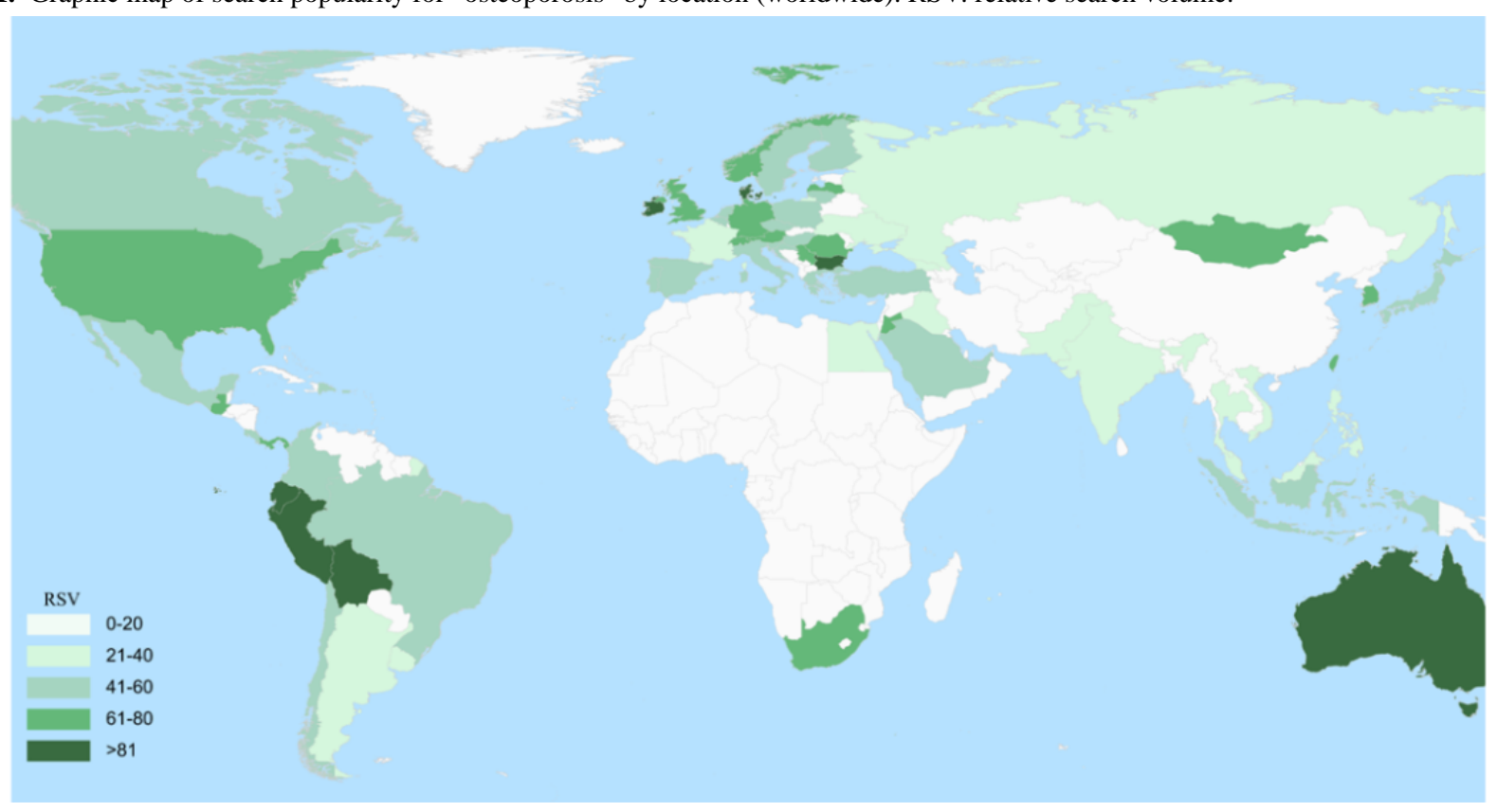

Global Search Trend and Seasonal Patterns for RSV of "Osteoporosis"

On a worldwide scale, there was a descending trend of RSV for “osteoporosis" from January 2004 to December 2014, and a slowly increasing trend from January 2015 to December 2019 (Figure 2A). Moreover, cosinor analysis suggested a significant seasonal pattern in RSV for "osteoporosis" $(P=.01)$, with a peak in March and a trough in September (Figure 2B and Table 1).

Figure 2. Time series plots for the worldwide relative search volume of osteoporosis from January 01, 2004, to December 31, 2019 (A), and the plots of cosinor models for the seasonal variation in the worldwide relative search volume of osteoporosis (B).

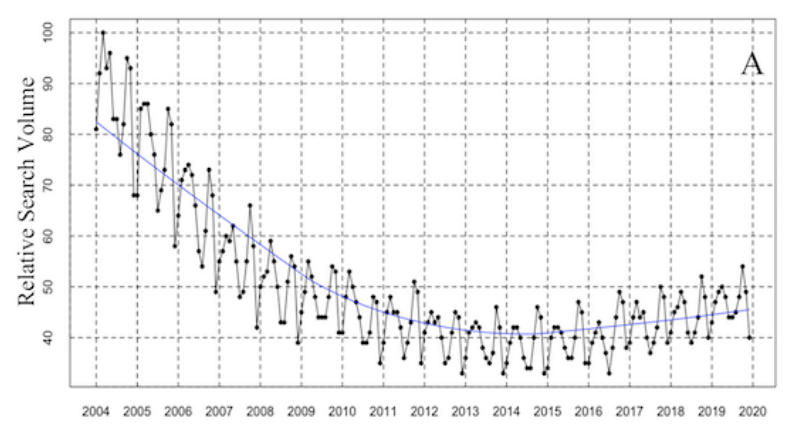

Date (year)

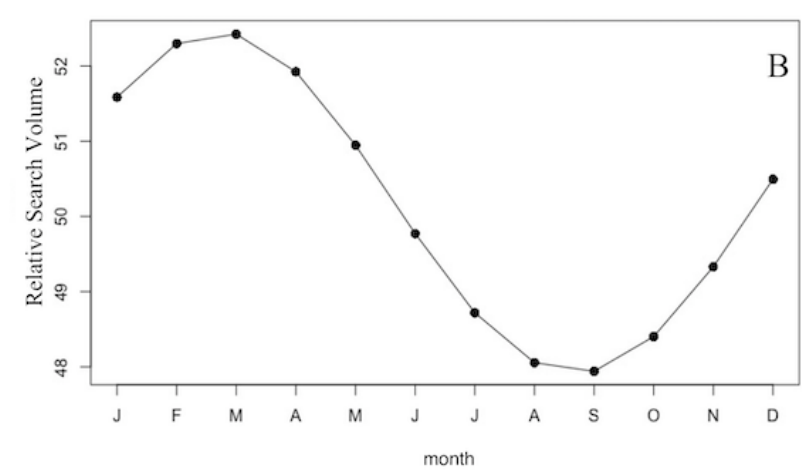

month

Table 1. The seasonal variations in relative search volume for "osteoporosis."

\begin{tabular}{|c|c|c|c|c|c|}
\hline Location & Number of observations & Amplitude & Phase month & Low point month & $P$ value $^{\mathrm{a}}$ \\
\hline Worldwide & 192 & 2.3 & 2.7 & 8.7 & .01 \\
\hline Australia & 192 & 7.3 & 6.3 & 12.3 & $<.001$ \\
\hline New Zealand & 192 & 2.7 & 5.7 & 11.7 & $<.001$ \\
\hline Canada & 192 & 6.2 & 1.5 & 7.5 & $<.001$ \\
\hline Ireland & 192 & 3.6 & 2.0 & 8.0 & $<.001$ \\
\hline UK & 192 & 5.7 & 2.2 & 8.2 & $<.001$ \\
\hline USA & 192 & 4.2 & 1.7 & 7.7 & $<.001$ \\
\hline
\end{tabular}

${ }^{\text {a }}$ Statistical significance was set as $P$ value $<.05$. 


\section{Search Trend and Seasonal Pattern for RSV of “Osteoporosis" in Six English-Speaking Countries}

A similar decreasing trend of RSV for "osteoporosis" was found in Australia, New Zealand, Ireland, and Canada from January 2004 to December 2019 (Figure 3A-D). In the UK, there was first a decreasing trend (from January 2004 to December 2012) and then a progressively increasing trend (from January 2013 to December 2019) of RSV for "osteoporosis" (Figure 3E). In addition, RSV for "osteoporosis" in the USA presented a descending trend from January 2004 to December 2014, and an increasing trend from January 2015 to December 2019 (Figure $3 \mathrm{~F})$.

Figure 3. Time series plots for the relative search volume of osteoporosis Australia (A), New Zealand (B), Canada (C), Ireland (D), UK (E), and USA (F) from January 01, 2004, to December 31, 2019.
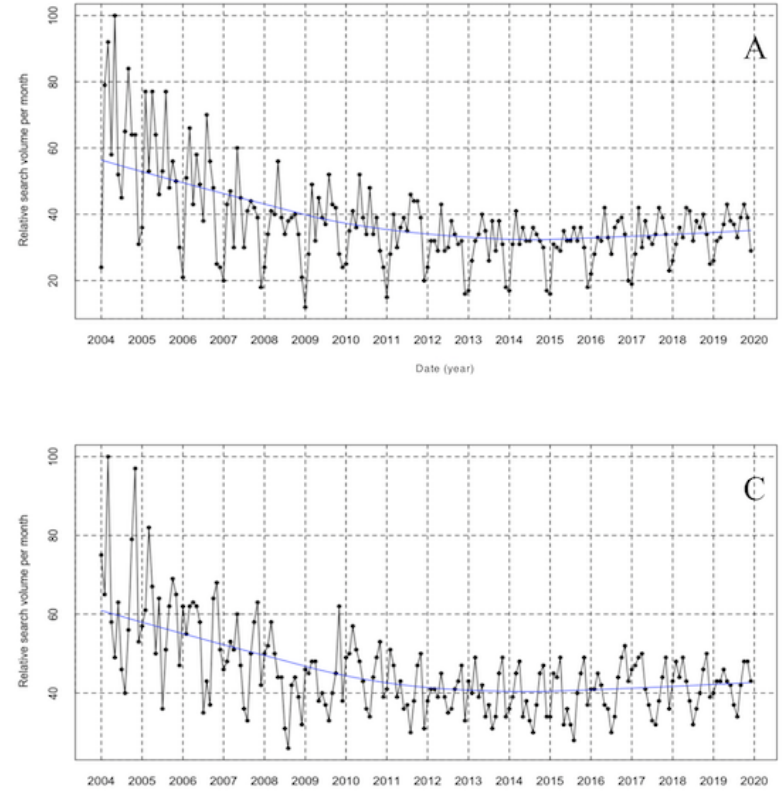

Dato (year)

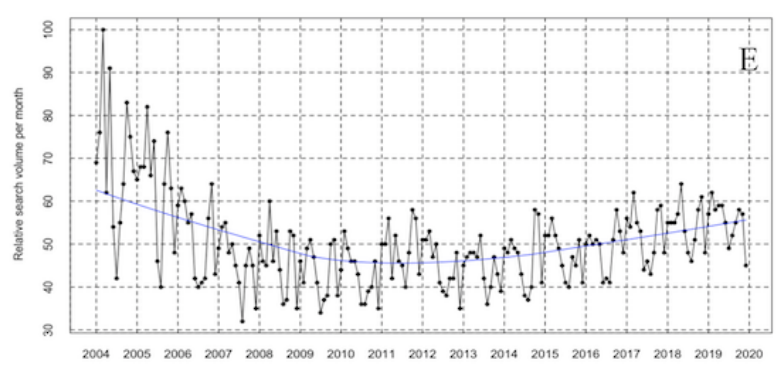

Dato (year)

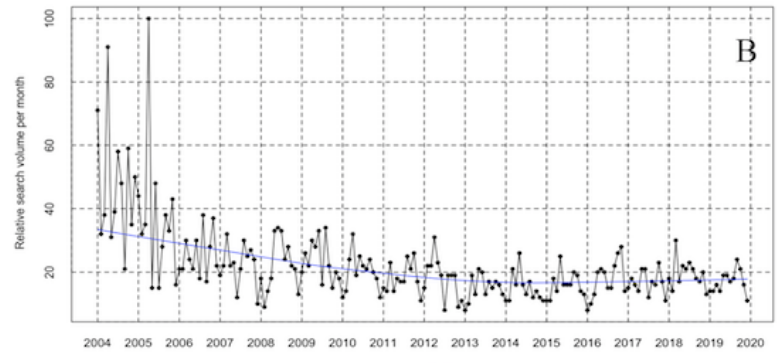

Dato (yeart)

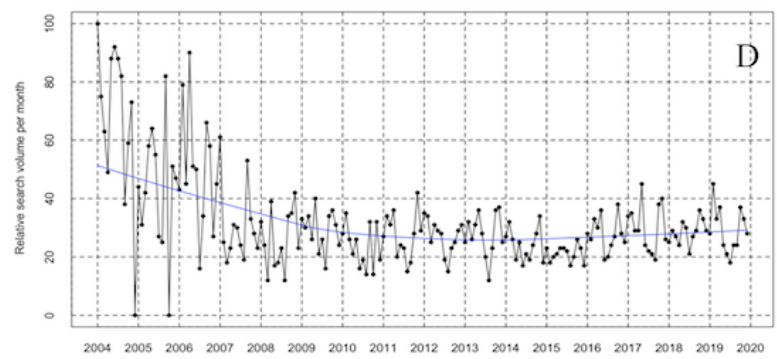

Date (yeart)

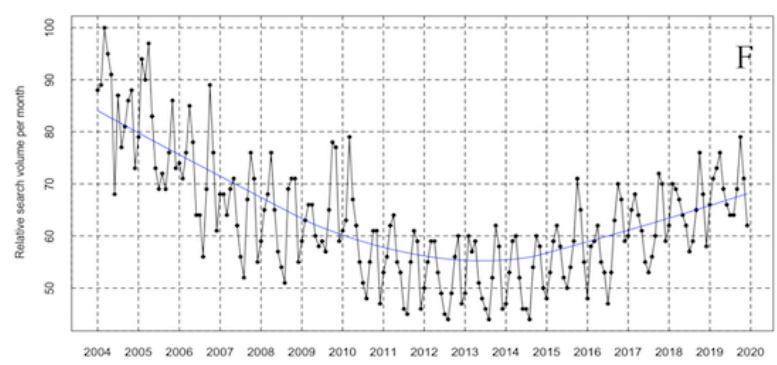

Date creart

The results of cosinor test showed significant seasonal variations of RSV for "osteoporosis" in Australia, New Zealand, Canada, Ireland, UK, and USA (all $P<.001$; Figure 4; Table 1). RSV for "osteoporosis" in 2 southern hemisphere countries (Australia and New Zealand) peaked in winter months (June/July) and was at its lowest point in summer months (December/January; Figure $4 \mathrm{~A}$ and $\mathrm{B}$ ), whereas in 4 northern hemisphere countries (Canada,

Ireland, UK, and USA), RSV for "osteoporosis" showed a peak in winter months (January/February) and a nadir in late summer/early autumn months (July/August/September; Figure 4C-F). There was an approximate 6-month difference in RSV for "osteoporosis" between southern and northern hemisphere countries with a reversed meteorological month (Figure 4). 
Figure 4. The plots of cosinor models for the seasonal variation in the relative search volume of osteoporosis in Australia (A), New Zealand (B), Canada (C), Ireland (D), UK (E), and USA (F) from January 01, 2004, to December 31, 2019.
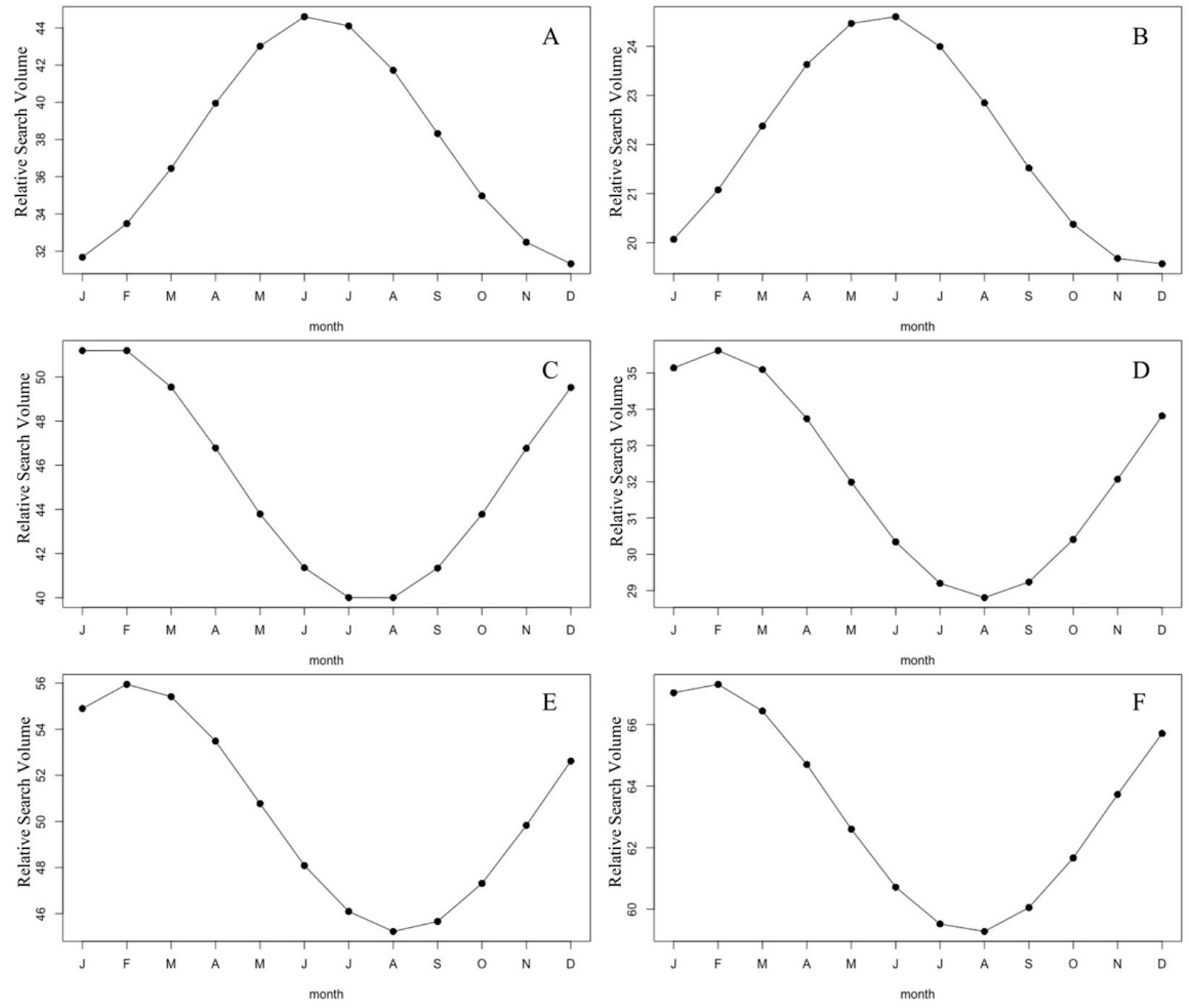

\section{Rise in Public Relative Search Topics Regarding "Osteoporosis"}

The rise in relative search topics was compared with the last period. The results showed that the global top rising topics were denosumab, fracture risk assessment tool (FRAX), bone tumor, hip fracture, osteomalacia, bone density, risk factor, osteoarthritis, arthritis, and osteopenia (Table 2). As for the 6 English-speaking countries, we observed that the most search rising topics were bone, bone density, osteopenia, osteoarthritis, risk factor, preventive healthcare, and the medications used for OP treatment (including denosumab, teriparatide, bisphosphonate; Table 2). 
Table 2. Public relative search topics rising in "osteoporosis."

\begin{tabular}{|c|c|c|c|c|c|c|c|}
\hline Rank & $\begin{array}{l}\text { Worldwide } \\
\text { Search topics } \\
\text { (\% rising) }\end{array}$ & $\begin{array}{l}\text { Australia } \\
\text { Search topics } \\
\text { (\% rising) }\end{array}$ & $\begin{array}{l}\text { New Zealand } \\
\text { Search topics } \\
\text { (\% rising) }\end{array}$ & $\begin{array}{l}\text { Canada } \\
\text { Search topics } \\
\text { (\% rising) }\end{array}$ & $\begin{array}{l}\text { Ireland } \\
\text { Search topics } \\
\text { (\% rising) }\end{array}$ & $\begin{array}{l}\text { UK } \\
\text { Search topics } \\
\text { (\% rising) }\end{array}$ & $\begin{array}{l}\text { USA } \\
\text { Search topics } \\
\text { (\% rising) }\end{array}$ \\
\hline 1 & $\begin{array}{l}\text { Denosumab } \\
\text { (breakout }^{\mathrm{a}} \text { ) }\end{array}$ & $\begin{array}{l}\text { Bone } \\
\text { (breakout) }\end{array}$ & $\begin{array}{l}\text { Bone } \\
\text { (breakout) }\end{array}$ & $\begin{array}{l}\text { Osteoarthritis } \\
\text { (breakout) }\end{array}$ & $\begin{array}{l}\text { Bone } \\
\text { (breakout) }\end{array}$ & $\begin{array}{l}\text { Bone density } \\
\text { (breakout) }\end{array}$ & $\begin{array}{l}\text { Risk factor } \\
\text { (breakout) }\end{array}$ \\
\hline 2 & $\begin{array}{l}\text { FRAX }^{\mathrm{b}} \\
\text { (breakout) }\end{array}$ & $\begin{array}{l}\text { Calcium } \\
\text { (breakout) }\end{array}$ & $\begin{array}{l}\text { Osteoarthritis } \\
\text { (breakout) }\end{array}$ & $\begin{array}{l}\text { Guideline } \\
\text { (breakout) }\end{array}$ & $\begin{array}{l}\text { Osteoarthritis } \\
\text { (breakout) }\end{array}$ & $\begin{array}{l}\text { Osteopenia } \\
\text { (breakout) }\end{array}$ & $\begin{array}{l}\text { Denosumab } \\
\text { (breakout) }\end{array}$ \\
\hline 3 & $\begin{array}{l}\text { Bone tumor } \\
\text { (breakout) }\end{array}$ & $\begin{array}{l}\text { Bone density } \\
\text { (breakout) }\end{array}$ & $\begin{array}{l}\text { Calcium } \\
\text { (breakout) }\end{array}$ & $\begin{array}{l}\text { Denosumab } \\
\text { (breakout) }\end{array}$ & $\begin{array}{l}\text { Irish Osteoporosis } \\
\text { Society (breakout) }\end{array}$ & $\begin{array}{l}\text { Dual-energy X-ray } \\
\text { absorptiometry } \\
\text { (breakout) }\end{array}$ & $\begin{array}{l}\text { Teriparatide } \\
\text { (breakout) }\end{array}$ \\
\hline 4 & $\begin{array}{l}\text { Hip fracture } \\
\text { (breakout) }\end{array}$ & $\begin{array}{l}\text { Preventive health- } \\
\text { care (breakout) }\end{array}$ & $\begin{array}{l}\text { Vitamin D } \\
\text { (breakout) }\end{array}$ & $\begin{array}{l}\text { Bisphosphonate } \\
\text { (breakout) }\end{array}$ & $\begin{array}{l}\text { Calcium } \\
\text { (breakout) }\end{array}$ & $\begin{array}{l}\text { Osteomalacia } \\
\text { (breakout) }\end{array}$ & $\begin{array}{l}\text { Ibandronic acid } \\
\text { (breakout) }\end{array}$ \\
\hline 5 & $\begin{array}{l}\text { Osteomalacia } \\
(1100)\end{array}$ & $\begin{array}{l}\text { Osteopenia } \\
\text { (breakout) }\end{array}$ & $\begin{array}{l}\text { Osteomalacia } \\
\text { (breakout) }\end{array}$ & $\begin{array}{l}\text { Risk factor } \\
\text { (breakout) }\end{array}$ & $\begin{array}{l}\text { Osteopenia } \\
\text { (breakout) }\end{array}$ & $\begin{array}{l}\text { FRAX } \\
\text { (breakout) }\end{array}$ & $\begin{array}{l}\text { Osteomyelitis } \\
\text { (breakout) }\end{array}$ \\
\hline 6 & $\begin{array}{l}\text { Bone density } \\
(550)\end{array}$ & $\begin{array}{l}\text { Rheumatoid arthri- } \\
\text { tis (breakout) }\end{array}$ & $\begin{array}{l}\text { Bone density } \\
\text { (breakout) }\end{array}$ & $\begin{array}{l}\text { Risedronic acid } \\
\text { (breakout) }\end{array}$ & $\begin{array}{l}\text { Royal Osteoporo- } \\
\text { sis Society (break- } \\
\text { out) }\end{array}$ & $\begin{array}{l}\text { Osteoarthritis } \\
(750)\end{array}$ & $\begin{array}{l}\text { Osteogenesis } \\
\text { imperfecta } \\
\text { (breakout) }\end{array}$ \\
\hline 7 & $\begin{array}{l}\text { Risk factor } \\
(450)\end{array}$ & $\begin{array}{l}\text { Risk factor } \\
\text { (breakout) }\end{array}$ & $\begin{array}{l}\text { Osteopenia } \\
\text { (breakout) }\end{array}$ & $\begin{array}{l}\text { Bone } \\
(650)\end{array}$ & None & $\begin{array}{l}\text { Calcium } \\
(300)\end{array}$ & $\begin{array}{l}\text { Mineral } \\
\text { (breakout) }\end{array}$ \\
\hline 8 & $\begin{array}{l}\text { Osteoarthritis } \\
(400)\end{array}$ & $\begin{array}{l}\text { Denosumab } \\
\text { (breakout) }\end{array}$ & $\begin{array}{l}\text { Osteoporosis } \\
(40)\end{array}$ & $\begin{array}{l}\text { Osteoporosis } \\
\text { (190) }\end{array}$ & None & $\begin{array}{l}\text { Preventive health- } \\
\text { care }(250)\end{array}$ & $\begin{array}{l}\text { Osteoarthritis } \\
(950)\end{array}$ \\
\hline 9 & $\begin{array}{l}\text { Arthritis } \\
(250)\end{array}$ & $\begin{array}{l}\text { Osteoarthritis } \\
(300)\end{array}$ & None & $\begin{array}{l}\text { Preventive health- } \\
\text { care (180) }\end{array}$ & None & $\begin{array}{l}\text { Osteoporosis } \\
(150)\end{array}$ & $\begin{array}{l}\text { Risk } \\
(450)\end{array}$ \\
\hline 10 & $\begin{array}{l}\text { Osteopenia } \\
(140)\end{array}$ & $\begin{array}{l}\text { Osteoporosis } \\
\text { (190) }\end{array}$ & None & $\begin{array}{l}\text { Bone density } \\
\text { (170) }\end{array}$ & None & $\begin{array}{l}\text { Bone } \\
(60)\end{array}$ & $\begin{array}{l}\text { Bone } \\
(200)\end{array}$ \\
\hline
\end{tabular}

a"Breakout" represents that the search term grew by more than $5000 \%$ compared with previous period.

${ }^{b}$ FRAX: fracture risk assessment tool.

\section{Discussion}

\section{Principal Findings}

In this study, we observed that the global internet search interest in "osteoporosis" steadily decreased from January 2004 to December 2014, whereas it slowly increased from January 2015 to December 2019. In addition, the presence of seasonal pattern in RSV for "osteoporosis" was revealed, with a peak in March and a trough in September. Moreover, we have investigated the RSV for "osteoporosis" among 6 English-speaking countries, which provided a good representation of countries in both northern and southern hemispheres. Similar change trends of RSV for "osteoporosis" were found for USA and UK as well; however, descending trends of RSV for "osteoporosis" were noted for Australia, New Zealand, Ireland, and Canada. Furthermore, the seasonal variations in RSV for "osteoporosis" among 6 English-speaking countries were confirmed, with a peak in late winter/early spring months and nadir in late summer/early autumn months. There was a nearly 6-month difference in the RSV for "osteoporosis" between southern/northern hemisphere countries with a reversed meteorological month, suggesting the presence of seasonal variations rather than calendar-driven patterns. The dynamic trends in "osteoporosis" could provide insights into the epidemiology of OP, as well as help care professionals and policy makers anticipate and prepare for this disease.

Rise in relative search topics on OP was also analyzed, with "denosumab" and "FRAX" identified as the top 2 global rising topics. Among 6 English-speaking countries, "bone" and "medications used for osteoporosis treatment" represented 2 of the most searched topics. Denosumab, also called receptor activator of nuclear factor-kappa B (RANK) ligand inhibitor, is a human monoclonal antibody used to increase bone mass and strength in the treatment of OP. The similar public search topic rising of "medications used for osteoporosis treatment" worldwide and in 6 English-speaking countries reflects the increasing public awareness of the treatment for OP other than the disease itself. FRAX is a diagnostic tool used to evaluate the probability of incurring an osteoporotic fracture. This topic rising may imply the public concerns about the possible osteoporotic fracture risk. The search topic rising interests in OP are of great importance for doctors and nurses, as they can capture the fluctuations of fast-growing topics of patients with $\mathrm{OP}$ and provide timely health promotion and education.

A number of studies have investigated the seasonal variation in OP presentation, and suggested that the seasonal variation in vitamin $\mathrm{D}$ concentration may be relevant to the occurrence of OP [29-32]. In a Greek cohort of 596 postmenopausal women 
with OP, there was a seasonal variation in serum levels of 25-hydroxy vitamin D [25(OH)D], with the highest and lowest $25(\mathrm{OH}) \mathrm{D}$ levels noted in late summer/early autumn months (August/September/October) and late winter/early spring months (March), respectively. Klenk et al [33] have also demonstrated a seasonal effect on the serum $25(\mathrm{OH}) \mathrm{D}$ levels in southern Germany, with the minimum $25(\mathrm{OH}) \mathrm{D}$ serum level noted in March and the maximum in August. Another study in a Romanian population [34] also supported the association of seasonal variation with serum $25(\mathrm{OH}) \mathrm{D}$ level (highest in September and lowest in March) regardless of study subgroups. It has been demonstrated that vitamin $\mathrm{D}$ deficiency impairs bone mineralization and increases bone turnover, thus accelerating bone loss $[35,36]$. Several studies have also reported that humans in colder regions showed low cortical thickness and bone mineral density, which result in accelerated bone loss with aging [37-39]. The dynamic change of serum 25(OH)D levels may thus have an effect on the bone mass and bone architecture and play a key role in the seasonal variation in OP.

\section{Limitations}

Nevertheless, this study has several limitations that need to be acknowledged. First, Google Trends data did not measure the prevalence, but rather contained the RSV that might be influenced by several confounders. Second, the presence of already known facts and consensus could affect people's preference when searching the related term of interest. Furthermore, the influence of politics and media was evident in the trends of search volumes, which may result in sampling bias.

Despite these limitations, our study also has several strengths. The study included a large and exhaustive amount of data with a long time span, thus making the results more representative and reliable as compared with a cross-sectional study. Furthermore, the findings of this study are helpful for public health officials to facilitate aid and optimize positive health outcomes by providing resources at the best time for intervention, especially when a majority of people with health-related information needs concerning OP are engaged in the process of information seeking.

\section{Conclusions}

Overall, this study revealed a slow global increase of internet search for "osteoporosis" in recent years, and also showed a significant seasonal variation in global RSV for "osteoporosis." In addition, the presence of seasonal patterns in RSV for "osteoporosis" was found in 6 English-speaking countries. Public relative search rising topics regarding "osteoporosis" indicated the major public concerns about this disease. This study also provided evidence about the search interest of public and dynamic trends in OP through an internet search, which could provide an initial contact point for patients experiencing symptoms, and may potentially be used to expedite necessary medical evaluation. In addition, as compared with a traditional epidemiological study, web-based data could be used as a supplement to the traditional surveillance data for the early control and prevention of this disease.

\section{Acknowledgments}

We thank all the people who participated in this study.

\section{Authors' Contributions}

PW and SFL conceived the presented idea. PW and QX developed the theory and performed the computations. RRC and FYD verified the analytical methods. All authors discussed the results and contributed to the final manuscript.

\section{Conflicts of Interest}

None declared.

\section{References}

1. Rizzoli R. Postmenopausal osteoporosis: Assessment and management. Best Pract Res Clin Endocrinol Metab 2018 Oct;32(5):739-757. [doi: 10.1016/j.beem.2018.09.005] [Medline: 30449552]

2. Bragg S, Bain J, Ramsetty A. Endocrine Conditions in Older Adults: Osteoporosis. FP Essent 2018 Nov;474:11-19. [Medline: 30427648]

3. Torrente-Segarra V, Roig-Vilaseca D. Denosumab mid-term densitometric gain in postmenopausal osteoporosis women in clinical practice: comment on "Variability of denosumab densitometric response in postmenopausal osteoporosis". Rheumatol Int 2018 Jun;38(6):1161-1162. [doi: 10.1007/s00296-018-4007-3] [Medline: 29546636]

4. Atik OS, Gunal I, Korkusuz F. Burden of osteoporosis. Clin Orthop Relat Res 2006 Feb;443:19-24. [doi: 10.1097/01.blo.0000200248.34876.fe] [Medline: 16462421]

5. Lane NE. Epidemiology, etiology, and diagnosis of osteoporosis. Am J Obstet Gynecol 2006 Feb;194(2 Suppl):S3-11. [doi: 10.1016/j.ajog.2005.08.047] [Medline: 16448873]

6. Gonçalves CF, Meng Q. Timing metabolism in cartilage and bone: links between circadian clocks and tissue homeostasis. J Endocrinol 2019 Aug 01;243(3):R29-R46. [doi: 10.1530/JOE-19-0256] [Medline: 31470415]

7. Farman HH, Gustafsson KL, Henning P, Grahnemo L, Lionikaite V, Movérare-Skrtic S, et al. Membrane estrogen receptor $\alpha$ is essential for estrogen signaling in the male skeleton. J Endocrinol 2018 Dec 01;239(3):303-312. [doi: 10.1530/JOE-18-0406] [Medline: $\underline{\text { 30400010] }}$ 
8. Park TH, Kim WI, Park S, Ahn J, Cho MK, Kim S. Public Interest in Acne on the Internet: Comparison of Search Information From Google Trends and Naver. J Med Internet Res 2020 Oct 26;22(10):e19427 [FREE Full text] [doi: 10.2196/19427] [Medline: $\underline{33104003}$ ]

9. Syamsuddin M, Fakhruddin M, Sahetapy-Engel JTM, Soewono E. Causality Analysis of Google Trends and Dengue Incidence in Bandung, Indonesia With Linkage of Digital Data Modeling: Longitudinal Observational Study. J Med Internet Res 2020 Jul 24;22(7):e17633 [FREE Full text] [doi: 10.2196/17633] [Medline: 32706682]

10. Eysenbach G. Infodemiology and infoveillance tracking online health information and cyberbehavior for public health. Am J Prev Med 2011 May;40(5 Suppl 2):S154-S158. [doi: 10.1016/j.amepre.2011.02.006] [Medline: 21521589]

11. Eysenbach G. Infodemiology and infoveillance: framework for an emerging set of public health informatics methods to analyze search, communication and publication behavior on the Internet. J Med Internet Res 2009;11(1):e11 [FREE Full text] [doi: 10.2196/jmir.1157] [Medline: 19329408]

12. Mavragani A. Infodemiology and Infoveillance: Scoping Review. J Med Internet Res 2020 Apr 28;22(4):e16206 [FREE Full text] [doi: 10.2196/16206] [Medline: 32310818]

13. Bernardo TM, Rajic A, Young I, Robiadek K, Pham MT, Funk JA. Scoping review on search queries and social media for disease surveillance: a chronology of innovation. J Med Internet Res 2013;15(7):e147 [FREE Full text] [doi: 10.2196/jmir.2740] [Medline: 23896182]

14. Eysenbach G. Infodemiology: tracking flu-related searches on the web for syndromic surveillance. AMIA Annu Symp Proc 2006:244-248 [FREE Full text] [Medline: 17238340]

15. Mavragani A, Ochoa G. Google Trends in Infodemiology and Infoveillance: Methodology Framework. JMIR Public Health Surveill 2019 May 29;5(2):e13439 [FREE Full text] [doi: 10.2196/13439] [Medline: 31144671]

16. Bragazzi NL, Barberis I, Rosselli R, Gianfredi V, Nucci D, Moretti M, et al. How often people google for vaccination: Qualitative and quantitative insights from a systematic search of the web-based activities using Google Trends. Hum Vaccin Immunother 2017 Feb;13(2):464-469. [doi: 10.1080/21645515.2017.1264742] [Medline: 27983896]

17. Hossain L, Kam D, Kong F, Wigand RT, Bossomaier T. Social media in Ebola outbreak. Epidemiol Infect 2016 Jul;144(10):2136-2143. [doi: 10.1017/S095026881600039X] [Medline: 26939535]

18. Mavragani A, Sampri A, Sypsa K, Tsagarakis KP. Integrating Smart Health in the US Health Care System: Infodemiology Study of Asthma Monitoring in the Google Era. JMIR Public Health Surveill 2018 Mar 12;4(1):e24 [FREE Full text] [doi: 10.2196/publichealth.8726] [Medline: 29530839]

19. Phelan N, Kelly JC, Moore DP, Kenny P. The effect of the metal-on-metal hip controversy on Internet search activity. Eur J Orthop Surg Traumatol 2014 Oct;24(7):1203-1210. [doi: 10.1007/s00590-013-1399-3] [Medline: 24390041]

20. Mavragani A, Ochoa G, Tsagarakis KP. Assessing the Methods, Tools, and Statistical Approaches in Google Trends Research: Systematic Review. J Med Internet Res 2018 Nov 06;20(11):e270 [FREE Full text] [doi: 10.2196/jmir.9366] [Medline: 30401664$]$

21. Yang AC, Huang NE, Peng C, Tsai S. Do seasons have an influence on the incidence of depression? The use of an internet search engine query data as a proxy of human affect. PLoS One 2010 Oct 28;5(10):e13728 [FREE Full text] [doi: 10.1371/journal.pone.0013728] [Medline: 21060851]

22. Ayers JW, Althouse BM, Allem J, Rosenquist JN, Ford DE. Seasonality in seeking mental health information on Google. Am J Prev Med 2013 May;44(5):520-525. [doi: 10.1016/j.amepre.2013.01.012] [Medline: 23597817]

23. Cervellin G, Comelli I, Lippi G. Is Google Trends a reliable tool for digital epidemiology? Insights from different clinical settings. J Epidemiol Glob Health 2017 Sep;7(3):185-189 [FREE Full text] [doi: 10.1016/j.jegh.2017.06.001] [Medline: 28756828]

24. Schootman M, Toor A, Cavazos-Rehg P, Jeffe DB, McQueen A, Eberth J, et al. The utility of Google Trends data to examine interest in cancer screening. BMJ Open 2015;5(6):e006678 [FREE Full text] [doi: 10.1136/bmjopen-2014-006678] [Medline: $\underline{26056120]}$

25. Chang Y, Chiang W, Wang W, Lin C, Hung L, Tsai Y, et al. Google Trends-based non-English language query data and epidemic diseases: a cross-sectional study of the popular search behaviour in Taiwan. BMJ Open 2020 Jul 05;10(7):e034156 [FREE Full text] [doi: 10.1136/bmjopen-2019-034156] [Medline: $\underline{32624467]}$

26. Kardeş S. Seasonal variation in the internet searches for gout: an ecological study. Clin Rheumatol 2019 Mar;38(3):769-775. [doi: 10.1007/s10067-018-4345-2] [Medline: 30374747]

27. Barnett AG, Dobson AJ. Analysing Seasonal Health Data. Berlin, Germany: Springer; 2010.

28. Barnett A, Baker P, Dobson A. Analysing Seasonal Data. The R Journal 2012;4(1):5-10. [doi: 10.32614/rj-2012-001]

29. Aw D, Thain J, Ali A, Aung T, Chua WM, Sahota O, et al. Predicting fracture risk in osteoporosis: the use of fracture prediction tools in an osteoporosis clinic population. Postgrad Med J 2016 May;92(1087):267-270. [doi: 10.1136/postgradmedj-2015-133454] [Medline: 26792635]

30. Andersen R, Mølgaard C, Skovgaard LT, Brot C, Cashman KD, Chabros E, et al. Teenage girls and elderly women living in northern Europe have low winter vitamin D status. Eur J Clin Nutr 2005 Apr;59(4):533-541 [FREE Full text] [doi: 10.1038/sj.ejcn.1602108] [Medline: 15714215] 
31. van der Wielen RP, Löwik MR, van den Berg H, de Groot LC, Haller J, Moreiras O, et al. Serum vitamin D concentrations among elderly people in Europe. Lancet 1995 Jul 22;346(8969):207-210. [doi: 10.1016/s0140-6736(95)91266-5] [Medline: 7616799]

32. Hansen L, Tjønneland A, Køster B, Brot C, Andersen R, Cohen AS, et al. Vitamin D Status and Seasonal Variation among Danish Children and Adults: A Descriptive Study. Nutrients 2018 Nov 20;10(11):1801 [FREE Full text] [doi: 10.3390/nu10111801] [Medline: 30463277]

33. Klenk J, Rapp K, Denkinger MD, Nagel G, Nikolaus T, Peter R, et al. Seasonality of vitamin D status in older people in Southern Germany: implications for assessment. Age Ageing 2013 May;42(3):404-408. [doi: 10.1093/ageing/aft042] [Medline: 23542723]

34. Niculescu DA, Capatina CAM, Dusceac R, Caragheorgheopol A, Ghemigian A, Poiana C. Seasonal variation of serum vitamin D levels in Romania. Arch Osteoporos 2017 Dec 11;12(1):113. [doi: 10.1007/s11657-017-0407-3] [Medline: 29230557]

35. Looker AC. Serum 25-hydroxyvitamin D and risk of major osteoporotic fractures in older U.S. adults. J Bone Miner Res 2013 May;28(5):997-1006 [FREE Full text] [doi: 10.1002/jbmr.1828] [Medline: 23184640]

36. Sai AJ, Walters RW, Fang X, Gallagher JC. Relationship between vitamin D, parathyroid hormone, and bone health. J Clin Endocrinol Metab 2011 Mar;96(3):E436-E446 [FREE Full text] [doi: 10.1210/jc.2010-1886] [Medline: 21159838]

37. Leslie WD, Weiler HA, Lix LM, Nyomba BLG. Body composition and bone density in Canadian White and Aboriginal women: the First Nations Bone Health Study. Bone 2008 May;42(5):990-995. [doi: 10.1016/j.bone.2008.01.018] [Medline: 18329354]

38. Leslie WD, Metge CJ, Weiler HA, Doupe M, Wood Steiman P, O'Neil JD. Bone density and bone area in Canadian Aboriginal women: the First Nations Bone Health Study. Osteoporos Int 2006 Dec;17(12):1755-1762. [doi: 10.1007/s00198-006-0184-0] [Medline: 16960648]

39. Wallace IJ, Nesbitt A, Mongle C, Gould ES, Grine FE. Age-related variation in limb bone diaphyseal structure among Inuit foragers from Point Hope, northern Alaska. Arch Osteoporos 2014;9:202. [doi: 10.1007/s11657-014-0202-3] [Medline: 25491658]

\section{Abbreviations \\ 25(OH)D: 25-hydroxy vitamin D \\ FRAX: fracture risk assessment tool \\ OP: osteoporosis \\ RSV: relative search volume}

Edited by R Kukafka; submitted 01.11.20; peer-reviewed by A Mavragani, ZXu; comments to author 26.11.20; revised version received
22.12.20; accepted 27.04.21; published 05.07.21
Please cite as:
Wang P, Xu Q, Cao RR, Deng FY, Lei SF
Global Public Interests and Dynamic Trends in Osteoporosis From 2004 to 2019: Infodemiology Study
J Med Internet Res $2021 ; 23(7):$ e25422
URL: $\underline{\text { https://www.jmir.org/2021/7/e25422 }}$
doi: $\underline{10.2196 / 25422}$
PMID:

CPeng Wang, Qing Xu, Rong-Rong Cao, Fei-Yan Deng, Shu-Feng Lei. Originally published in the Journal of Medical Internet Research (https://www.jmir.org), 05.07.2021. This is an open-access article distributed under the terms of the Creative Commons Attribution License (https://creativecommons.org/licenses/by/4.0/), which permits unrestricted use, distribution, and reproduction in any medium, provided the original work, first published in the Journal of Medical Internet Research, is properly cited. The complete bibliographic information, a link to the original publication on https://www.jmir.org/, as well as this copyright and license information must be included. 